\title{
IMPROVEMENT OF TECHNOLOGY AND MACHINES FOR GROWING POTATOES IN AGRICULTURE
}

\author{
Marat Salimzyanov ${ }^{1}$, Vladimir Pervushin ${ }^{1}$, Renat Shakirov ${ }^{1}$, Marat Kalimullin ${ }^{2}$ \\ ${ }^{1}$ Izhevsk State Agricultural Academy, Russia; ${ }^{2}$ Kazan State Agrarian University, Russia \\ salimmar@mail.ru, pervushin54@mail.ru, renmar@mail.ru, marat-kmn@yandex.ru
}

\begin{abstract}
The article proposes the improvement of the technology and complex of small-sized machines for growing potatoes in Russia, where most of $80 \%$ are cultivated by private farms and farmers with low crop cultivation in low-contour, clogged areas, with non-rotation, rare update of tubers, obsolete equipment and multioperation technology. Multiple mechanical tillages before planting and afterwards compact and spray the soil, which is undesirable for the soil condition, the need arises for one-time preparation of the field with a combined mounted tillage unit in one technological pass as deep cultivation and harrowing. Also, little use is made of combining several operations in one technological pass as comb formation, fertilizing, dressing and planting tubers with comb sealing. The care of potato plants is especially important in the initial period of vegetation before budding, since at this time the formation of the future crop and the need for the next few mechanical and chemical treatments occur, which leads to costs, spraying and compaction of the soil. Therefore, the creation of a mounted combined cultivator-sprayer that allows loosening the ridges and treating weeds, pests and diseases during the beginning and end of the growing season is enough for a favorable increase in potato productivity. The purpose of the study is to improve the technology of cultivating potatoes in small areas by creating combined and modernized small-sized agricultural machines and implements. The research tasks, ways of their solution and results are set.
\end{abstract}

Keywords: small-sized machines, combined tillage yell que, potato planter, cultivator-hiller-sprayer.

\section{Introduction}

Currently, in Russia, about $80 \%$ of potatoes are produced in the conditions of farms and personal subsidiary farms (PSF) of the population. Due to low crop cultivation, outdated equipment, technology, and a number of other reasons, the yield is low in most cases less than $20 \mathrm{t} \cdot \mathrm{ha}^{-1}$ and less often up to $30 \mathrm{t} \cdot \mathrm{ha}^{-1}$. This category of farms grows potatoes on ridges in special conditions $[1 ; 2]$ :

- small-scale (small) plots (according to statistics for the Volga Federal District (VFD) of Russia, the area of sown plots up to 3 ha is $28 \%$, from 3 to 8 ha $25 \%$ and from 9 to 33 ha $25 \%$;

- mobile power tools in the form of low-power tractors up to $60 \mathrm{~kW}$;

- small-sized, low-cost productive agricultural machines;

- areas that are clogged due to violation of technology or the inability and insufficiency of measures taken to ensure a favorable growth of potatoes;

- insufficient air balance in the soil ridge, which affects the nutrition of the potato plant;

- agricultural machines perform one technological operation.

The demand for ecological products grown using the technology of minimal chemical treatments is growing from year to year [3].

Crop productivity is the result of the interaction of many factors and conditions, the most important of which are: soil fertility, plant nature, soil and climatic conditions and mechanized tillage technology $[4 ; 5]$.

The justification of the technology and complex of machines for potato cultivation must be based on the condition of the technical base and workforce management, soil and climatic conditions, the financial situation of the economy and considering of the requirements for soil treatment, crop rotation, seed material, its preparation, planting and care during the growing season and a number of other organizational and technological problems $[1 ; 6-10]$.

The purpose of the research is to improve the technology of potato cultivation on small-scale plots by creating combined and modernizing small-sized agricultural machines and tools.

Research objectives:

- creation of a small-lumped soil structure with partial destruction of weeds when preparing it for planting in a single technological pass with a combined mounted tillage unit; 
- planting partially germinated pickled tubers with the application of mineral fertilizers and the formation of a dense ridge in one technological pass of an experimental potato planting mounted machine;

- care of potato plants during their growing season for a favorable growth and in the emergence after planting and post-emergence cultivation of the field before flowering of the potatoes in a combined (mechanical and chemical) way, with the aim of creating a loose layer around the tubers inside and outside the soil ridge and by spraying the latter to destroy weeds, pests and diseases, due to the modernized mounted cultivator-hiller-sprayer with rotary harrows;

- energy and resource saving.

\section{Materials and methods}

Preplanting soil preparation is carried out in spring, as soon as it is ripe for cultivation. At this time, early spring harrowing is carried out to preserve moisture and accelerate the germination of weeds, then perennial combed cultivators are plowing soil with a combined unit equipped with a harrow and destroy the germinated weeds with the simultaneous application of fertilizers.

Traditionally, when preparing the soil for planting, during the main ploughing of the soil, plows are combined with trailed tooth harrows BZTS -1,0, BZSS -1,0. As a result of the analysis of the operation of these combined units, the following main disadvantages should be noted [1]:

- on heavy soils, the teeth of the harrow do not provide high-quality cutting of the reservoir;

- on the headland, especially during sharp turns at the end of the headland, the harrows turn over and overlap each other;

- not suitable for plowing small areas farms and gardens - garden plots.

Agricultural and operational disadvantages of a traditional combined unit can be eliminated, if the plow is equipped with a mounted harrow-leveling device BV-1 (Fig. 1). Such a combined mounted unit eliminates the aforementioned disadvantages of a traditional arable unit and provides a smalllumpy soil structure, good field uniformity and partial weed control in one pass.

a)

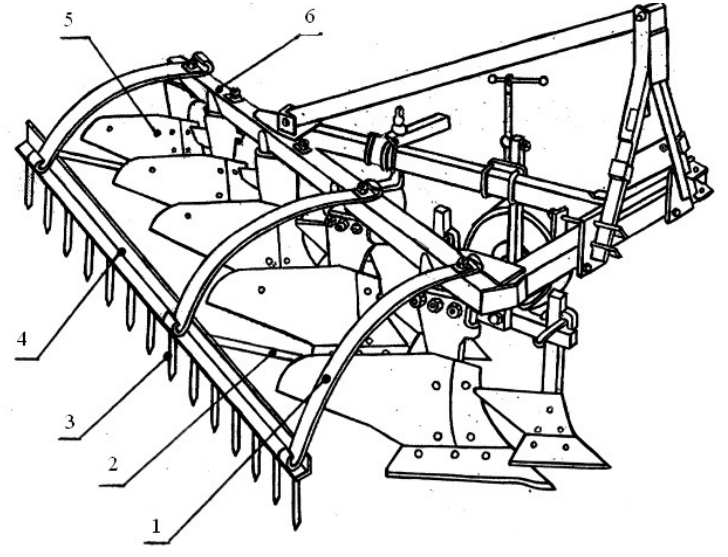

b)

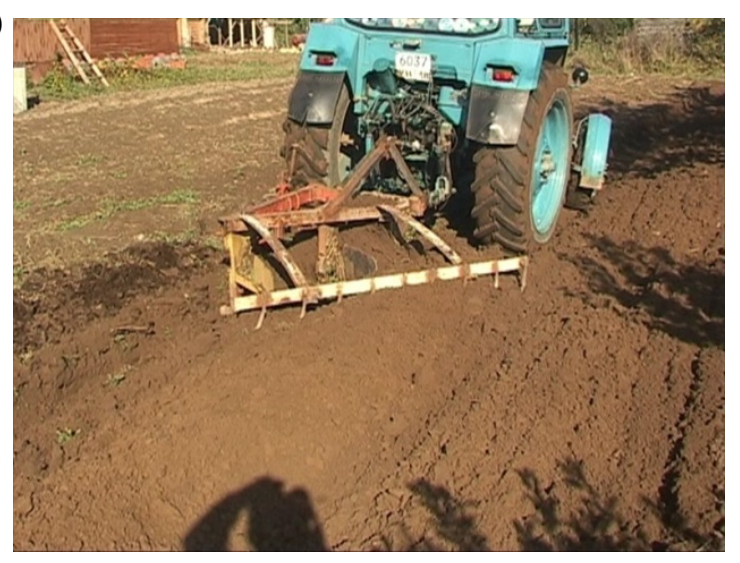

Fig. 1. Combined tillage unit: $a-$ unit diagram; $b-$ unit in operation; 1 - brace; 2 - stretching; 3 - teeth; 4 - harrow-comb; 5 - plow body; 6 - frame

The gun has a frame 6 , plow bodies 5 , a harrow-comb 4 with teeth 3 and a brace 1 . Plow bodies 5 are mounted directly on the frame 6 , and the harrow-comb 4 via spring leaves and mount extensions 2 and on the frame of the plow .

During operation, the plow bodies 5 cut and turned over, and the harrow is a rake 2, levels the soil and combs out the weeds.

The adjustment of the depth of cultivation is achieved by changing the position of the harrow-tine rake height-adjustable stretch marks 2 . When shortening the stretch marks, the harrow-comb deepens, and when the stretchings are elongated, the depth of the cultivation decreases (Fig. 1).

The combined mounted tillage implement of the proposed design, in comparison with analogues, does not have a large metal consumption and is more convenient in operation. 
Comparative agro-technical and energy characteristics of machines for cultivation and harrowing the soil are presented in Table 1. The quality of crumbling soil was assessed by the presence of lumps with a diameter of more than $5 \mathrm{~cm}$ pcs per $\mathrm{m}^{-2}$.

\section{Comparative agro-technical and energy characteristics of machines for cultivation and harrowing the soil}

Table 1

\begin{tabular}{|c|c|c|c|}
\hline Indicator & $\begin{array}{c}\text { Analog serial } \\
\text { PLN-3-35 + BZTS-1.0 }\end{array}$ & $\begin{array}{c}\text { Development } \\
\text { PLN-3-35 + BV-1.0 }\end{array}$ & $\begin{array}{c}\text { Relationship } \\
\text { indicators, \% }\end{array}$ \\
\hline Agrotechnical speed, $\mathrm{km} \cdot \mathrm{h}^{-1}$ & \multicolumn{2}{|c|}{$5-12$} & 100 \\
\hline Working width, $\mathrm{m}$ & \multicolumn{2}{|c|}{1.05} & 100 \\
\hline Time utilization factor & 0.47 & 0.59 & 125 \\
\hline Productivity operational, ha $\cdot \mathrm{h}^{-1}$ & $0.44-0.59$ & $0.56-0.74$ & 125 \\
\hline Depth of processing, $\mathrm{cm}$ & \multicolumn{2}{|c|}{ up to 30} & 100 \\
\hline Weight, $\mathrm{kg}$ & $532(490+42)$ & 325 & 61 \\
\hline Dimensions, mm & $3500 \times 1500 \times 1200$ & $1800 \times 1500 \times 1000$ & $51.4 \times 100 \times 83.3$ \\
\hline Fuel consumption, $1 \cdot$ ha $^{-1}$ & $17.87-20.2$ & $15.52-18.45$ & $86.85-91.33$ \\
\hline Labor costs, people-h $\cdot$ ha $^{-1}$ & $2.27-1.70$ & $1.78-1.35$ & 150 \\
\hline $\begin{array}{l}\text { Cost of mechanical energy, } \\
\mathrm{J} \cdot \mathrm{ha}^{-1}\end{array}$ & 660910 & 574136 & 86.86 \\
\hline Degree of soil crumbling, $\%$ & 84 & 89 & 106 \\
\hline $\begin{array}{l}\text { Incorporation of crop } \\
\text { residues, } \%\end{array}$ & 95 & 99 & 104 \\
\hline Field alignment, \% & 93 & 96 & 103 \\
\hline Clumping soil, \% & 14 & 9 & 64 \\
\hline
\end{tabular}

Planting tubers. One of the most common ways to plant potatoes is to plant in pre-chopped combs. Therefore, after plowing, cutting of ridges with a height of $8-10 \mathrm{~cm}$ is carried out. This operation provokes seedlings of weeds, which are destroyed during planting and subsequent tillage, and allows planting without the use of markers.

For planting, the most productive varieties are used, the tubers must be subjected to pre-planting treatment (etched).Planting dates depend on the soil and climatic conditions and weediness of the site. If the field is relatively clean from weeds, then the potatoes are planted immediately after cutting the ridges, and if it is very clogged, then after 3-4 days in order to allow the weeds to germinate, and then destroy them in the white thread phase when planting. The tubers are planted to a depth of 5-6 cm in the ridges with a height of $8-10 \mathrm{~cm}$, with simultaneous rolling, which contributes to the destruction of lumps and better initial development of potatoes and the simultaneous germination of weeds in order to destroy the latter when caring for potato plants. Usually potato planters L-201; ST-2; CS-2 and other analogues are used.

For the simultaneous formation (cutting) of the ridge, dressing, planting of tubers and applying mineral fertilizers, it is proposed to use a two-row mounted experimental potato planter with an elevator design, Fig. 2. In front of the potato planter there are lancet puffers 4 , on the top of the frame there is a tuber bunker, a pickling tank and a container for mineral fertilizers (not shown in Fig. 2), equipped with a belt-spoon planting apparatus 3 and two paired drums 1 mounted on a tubular shaft 2 and they have the functions of supporting wheels [1].

The technological process takes place in one pass. When the pitiful tubers from the hopper are raked out, etched, and from the belt-spoon planting device 3 with mineral fertilizer without contacting, they are sent to the bottom of the furrow by the hoe prepared in front of the arrow leg, then sealed with the soil by spherical disks 5, forming a triangular ridge behind them. The drums 1 located behind the spherical disks, which serve as the support wheels, transform the comb into a trapezoidal shape, destroying lumps and rolling soil, creating favorable soil conditions for the germination of potato tubers and weeds, with the aim of destroying the latter during subsequent technological care 
operations. It is important that the tubers are laid not on the bottom of the treated layer, but on a loose pillow about $2 \mathrm{~cm}$ high, which provides better conditions for the initial development of potatoes.

a)

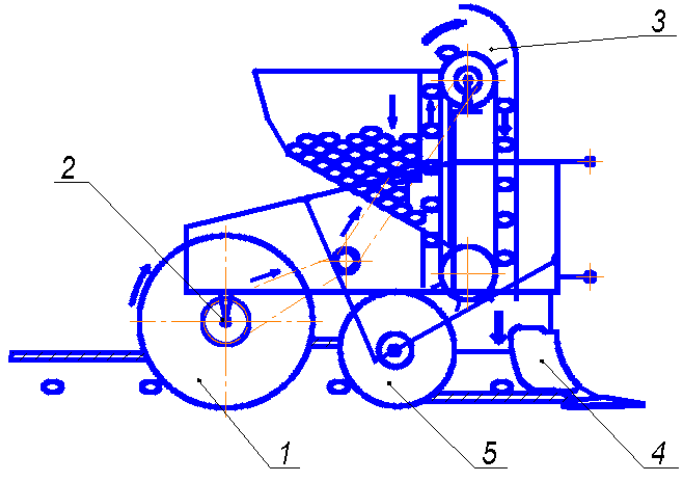

3 b)

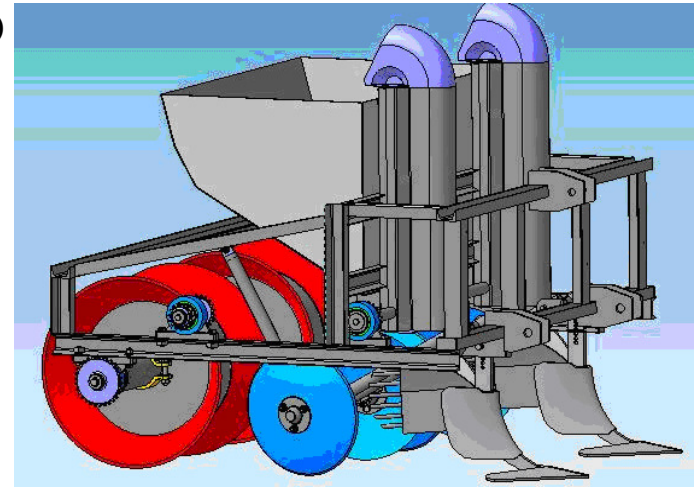

Fig. 2. Potato planter: $\mathrm{a}$ - technological plan; $\mathrm{b}-3 \mathrm{D}$ model; 1 - press drum; 2 - tubular shaft; 3 - belt-and-spoon planting apparatus; 4 - lancet paw hiller; 5 - spherical disks

The comparative technical characteristics of potato planters are presented in Table2.

Comparative technical characteristics of potato planters

Table 2

\begin{tabular}{|c|c|c|c|}
\hline Indicator & L-201 & $\begin{array}{l}\text { Experimental 2- } \\
\text { row potato planter }\end{array}$ & $\begin{array}{l}\text { Relationship } \\
\text { indicators, \% }\end{array}$ \\
\hline Aisle width, $\mathrm{cm}$ & \multicolumn{2}{|c|}{$62.5 ; 70 ; 75$} & 100 \\
\hline Agricultural speed, $\mathrm{km} \cdot \mathrm{h}^{-1}$, up to & \multicolumn{2}{|c|}{10} & 100 \\
\hline Hopper capacity, kg & 250 & 300 & 120 \\
\hline Working width, $\mathrm{m}$ & \multicolumn{2}{|c|}{1.05} & 100 \\
\hline Productivity, ha $\cdot \mathrm{h}^{-1}$ & \multicolumn{2}{|c|}{$0.57-1.14$} & 100 \\
\hline Depth of processing, $\mathrm{cm}$ & \multicolumn{2}{|c|}{$100-150$} & 100 \\
\hline Dimensions, mm & $1650 \times 1500 \times 1500$ & $2000 \times 1600 \times 1400$ & $121 \times 107 \times 93.3$ \\
\hline Weight, kg & 380 & 315 & 82.9 \\
\hline
\end{tabular}

Potato planting care. Caring for potato plants during the growing season is a mandatory set of measures, the proper use of which influences the yield and consists in combination of the combination and periodic sequence of mechanical, chemical and combined treatments to destroy weeds, pests, diseases and create a loosening layer around the tuber inside and outside the ridge . Mechanical processing is performed by cultivators of the brand CON-1.4/2.8 and the like, and chemical processing is performed by sprayers of the type OPN-200; OGR-200 and analogues.

The disadvantage of the mounted cultivator is the design of the fastening of the ridge made by casting, the presence of a parallelogram mechanism that is adjustable along the length of the upper link.

Namely, a change in the length of the upper thrust leads to the transition of the parallelogram mechanism to the trapezoidal mechanism, and as a result to a change in the angle of entry of the working bodies into the soil, an increase in its traction resistance and a decrease in the quality of rowspacings.

The aforementioned shortcomings are eliminated by the fact that in the cultivator the upper link is made not adjustable and equal in length to the lower link, which eliminates the change in the angle of entry of the working bodies into the soil when copying the microrelief of row spacing (Fig. 3).

The cultivator contains a transverse beam 1 carrying the working sections 2 . Section 1 is provided with a beam 3, upper thrust 6 , a diagonal 5 and a lower link 8 made of a $U$-shaped link and a link-link connecting the front 7 and rear 4 brackets. Section 2 rests on the copy wheel 10 adjustable and fixed in height. The front brackets are made in the form of T-shaped elements with a hinge having a transverse base equal to the transverse base of the lower U-shaped rod. 
a)
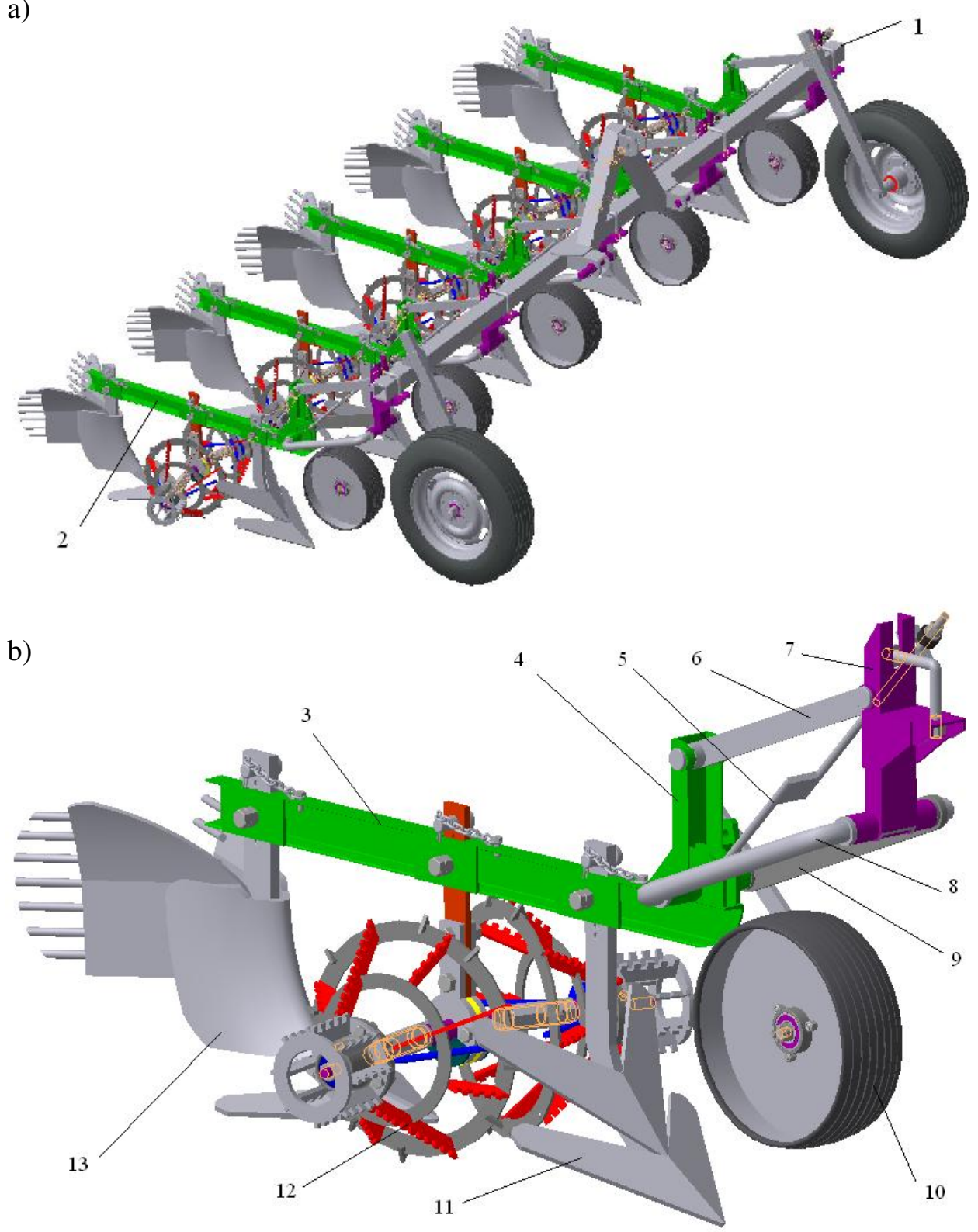

Fig. 3. 3D model cultivator CON-3M: a - cultivator; $b$ - cultivator working section; 1 - cross beam; 2 - working sections; 3 - beam; 4 - rear bracket; 5 - diagonal; 6 - upper thrust; 7 - front bracket; 8 - lower link; 9 - pull-lock; 10 - feeler wheel; 11 - three-tier lancet paw;

12 - rotary harrow; 13 - hiller-paw

The technological process is as follows. By changing the length of the upper link of the tractor, the beds of all working sections are adjusted to the horizontal position. By changing the position of the copying wheel 10 and the working bodies 11,12,13 in height, the working bodies are adjusted to a predetermined depth of tillage. The racks of the working bodies on the bed are fastened by tightening the bolts on the bed. In the process of cultivation, the bolts with a conical end securely hold the rack in the installed position in the conical recesses in the rack [1].

Pre-emergence treatment is carried out 12-14 days after planting by mechanical and chemical methods. At the same time, three-tiered paws located in the aisle trim weeds loosen the top layer of soil in a gentle mode to prevent damage to the root system of tubers when the ridge is shifted. Rotary borons that roll over the surface of the ridge drag and dump the top layer of soil and sprouted weeds into the row spacing. Hoppers loosen the soil to a great depth, drag weeds, destroying the connection of the root system with the soil, and build up a ridge to $13-15 \mathrm{~cm}$, on which herbicides are sprayed from the capacity of the cultivator-sprayer. 
After 21 days, the technological operation is repeated, increasing the height of the ridge to 22 $25 \mathrm{~cm}$ and sprayed for weeds, pests and diseases.

\section{Results}

The comparative agrotechnical characteristics of cultivators of inter-row cultivation of potato field are presented in Table 3.

Table 3

Comparative agrotechnical characteristics of cultivators of inter-row cultivation of potato field

\begin{tabular}{|c|c|c|c|}
\hline Indicator & $\begin{array}{c}\text { Analog serial } \\
\text { cultivator CON-2,8A }\end{array}$ & $\begin{array}{c}\text { Upgraded } \\
\text { cultivator } \mathrm{CON}-3\end{array}$ & $\begin{array}{r}\text { Relationship } \\
\text { indicators, \% }\end{array}$ \\
\hline Agrotechnical speed, $\mathrm{km} \cdot \mathrm{h}^{-1}$, up to & \multicolumn{2}{|l|}{10} & 100 \\
\hline Working width, $\mathrm{m}$ & 2.8 & 3 & 100 \\
\hline Productivity, ha $\cdot \mathrm{h}^{-1}$ & $2-2.8$ & $2.14-3$ & 107 \\
\hline Depth of processing, $\mathrm{cm}$ & \multicolumn{2}{|c|}{ up to $16 \mathrm{~cm}$} & 100 \\
\hline Weight (with hopper), kg & 851 & 852 & 100.2 \\
\hline Dimensions $(\mathrm{L} \times \mathrm{W} \times \mathrm{H}), \mathrm{mm}$ & $2450 \times 3200 \times 1620$ & $2230 \times 3290 \times 1240$ & $91 \times 103 \times 77$ \\
\hline Degree of soil crumbling, $\%$ & 91 & 96 & 105.5 \\
\hline Weed control, $\%$ & 95 & 99 & 104.2 \\
\hline $\begin{array}{l}\text { Degree of tuberized (uprooted) } \\
\text { tubers), } \%\end{array}$ & 1.9 & 1.6 & 84.2 \\
\hline
\end{tabular}

The results of comparison of technology and complex of machines for potato cultivation in agriculture are given in Table 4.

\section{Results of comparison of technology and complex of machines for potato cultivation in agriculture}

\begin{tabular}{|c|c|c|}
\hline \multirow{2}{*}{$\begin{array}{l}\text { Technological } \\
\text { operation }\end{array}$} & \multicolumn{2}{|c|}{ Complex of agricultural machines } \\
\hline & $\begin{array}{c}\text { Traditional technology on the } \\
70 \mathrm{~cm} \text { aisle } \\
\end{array}$ & $\begin{array}{c}\text { Improvement technology with } \\
\text { aisle } 75 \mathrm{~cm}\end{array}$ \\
\hline $\begin{array}{l}\text { Spring } \\
\text { harrowing }\end{array}$ & $\begin{array}{c}\text { SP-11 + 12BZTS-1 (hitch and trailed } \\
\text { harrows) }\end{array}$ & 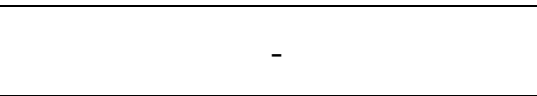 \\
\hline $\begin{array}{l}\text { Application of mineral } \\
\text { fertilizers }\end{array}$ & L-116 or other spreader & - \\
\hline $\begin{array}{l}\text { Spring } \\
\text { plowing }\end{array}$ & $\begin{array}{l}\text { PLN-3-35 + BZSS-1.0 } \\
\text { (plow and trailed harrow) }\end{array}$ & $\begin{array}{l}\text { PLN-3-35 + BV-1 (Combined } \\
\text { tillage mounted implement) }\end{array}$ \\
\hline $\begin{array}{l}\text { Creation (cutting) of the } \\
\text { ridge }\end{array}$ & CON-1.4/2.8 or another cultivator & - \\
\hline Planting & $\begin{array}{l}\text { L-201; ST-2; CS-2 or other potato } \\
\text { planter }\end{array}$ & $\begin{array}{l}\text { Experimental planters with the } \\
\text { introduction of mineral fertilizers } \\
\text { and the formation of ridges }\end{array}$ \\
\hline Weed control & $\begin{array}{c}\text { OPN-200 (OPN-400); ORG-200 or } \\
\text { other sprayers }\end{array}$ & $\begin{array}{l}\text { Surface treatment: harrowing, } \\
\text { hilling and spraying: } \\
\text { CONO-3: (CON-3M + OPN-200) }\end{array}$ \\
\hline Processing aisle & CON-1.4/2.8 or another cultivator & - \\
\hline Hilling 1st & CON-1.4/2.8 or another cultivator & - \\
\hline Hilling 2nd & CON-1.4/2.8 or another cultivator & Harrowing, mowing and spraying \\
\hline Weed control & $\begin{array}{c}\text { OPN-200 (OPN-400); ORG-200 or } \\
\text { other sprayers. }\end{array}$ & $\begin{array}{c}\text { with herbicides, insecticides, } \\
\text { fungicides }\end{array}$ \\
\hline $\begin{array}{l}\text { Pest and Disease } \\
\text { Control }\end{array}$ & $\begin{array}{l}\text { OPN-200 (OPN-400); ORG-200 or } \\
\text { other sprayers }\end{array}$ & $\begin{array}{c}\text { KONO-3: } \\
(\mathrm{KON}-3 \mathrm{M}+\mathrm{OPN}- \\
200)\end{array}$ \\
\hline
\end{tabular}


Table 4(continued)

\begin{tabular}{|l|c|c|}
\hline \multirow{2}{*}{\begin{tabular}{c}
\multirow{2}{*}{$\begin{array}{c}\text { Technological } \\
\text { operation }\end{array}$} \\
\cline { 2 - 3 }
\end{tabular}} & $\begin{array}{c}\text { Traditional technology on the } \\
\text { 70cm aisle }\end{array}$ & $\begin{array}{c}\text { Traditional technology on the } \\
\text { 70cm aisle }\end{array}$ \\
\hline Chopping Tops & KIR-1.5 and others & $\begin{array}{c}\text { BD-1.5 (Experimental topper } \\
\text { crusher) }\end{array}$ \\
\hline Potato harvesting & KTN-2V & KTN-2VM (Upgraded) \\
\hline $\begin{array}{l}\text { Autumn plowing and } \\
\text { harrowing }\end{array}$ & $\begin{array}{c}\text { PLN-3-35 + BZSS-1,0 } \\
\text { plow and trailed harrow) }\end{array}$ & $\begin{array}{c}\text { PLN-3-35 + BV-1 (Combined tillage } \\
\text { mounted implement) }\end{array}$ \\
\hline $\begin{array}{l}\text { Labor costs, man- } \\
\text { hours } \cdot \text { ha }^{-1}\end{array}$ & 149.8 & 141.3 \\
\hline Yield, $t \cdot$ ha $^{-1}$ & 17.9 & 19.4 \\
\hline
\end{tabular}

\section{Conclusions}

1. The improved technology of cultivating potatoes at a row spacing of $75 \mathrm{~cm}$ with a minimum number of treatments in small areas due to the creation of combined and modernization of smallsized agricultural machines and implements made it possible to ensure the favorable development of potato plants, thereby reducing the production costs by $5.7 \%$ and increasing the yield by $8.4 \%$.

2. The designed and tested combined mounted soil tillage unit PLN-3-3 + BV-1 with a low metal content of $m=325 \mathrm{~kg}$, based on a plow for simultaneous plowing and harrowing, provides high operational productivity up to $0.74 \mathrm{ha} \cdot \mathrm{h}^{-1}$, fine-grained soil structure, good field uniformity and partial weed control.

3. An experimental 2-row mounted potato planter with a small weight of up to $315 \mathrm{~kg}$ has been developed, which allows for cutting the ridges of the soil, dressing the tubers, planting, applying fertilizers and rolling the comb in one technological pass, in order to create a favorable friendly shoot of plants.

4. A 4-row mounted cultivator-hiller KON-3 with rotary harrows was developed, based on the modernization of the KON-2.8A cultivator for inter-row cultivation of the soil and caring for potato plants during the growing season mechanically to create a loose layer around the tubers inside and outside soil ridge and weed control, will increase the degree of cultivation by $5.5 \%$, the degree of weed control by $4.2 \%$ and reduce the degree of damage to tubers by $15.8 \%$.

5. It is proposed to develop the KONO-3 cultivator-okuchnik-sprayer by upgrading the KON-3 mounted cultivator-okuchnik and the OPN-200 mounted sprayer to perform a one-time technological pass using the combined (mechanical and chemical) method of inter-row tillage and caring for potato plants during their growing season for the purpose creating a loose layer around the tubers inside and outside the soil ridge and the destruction of weeds, pests and diseases, which will reduce labor costs and increase productivity.

\section{References}

[1] Первушин В.Ф., Медведев В. Г, Салимзянов М.З., Касимов Н. Г. Особенности усовершенствованной технологии возделывания картофеля в Удмуртии (Features of advanced potato cultivation technology in Udmurtia). Potatoes and vegetables. Journal/ No. 1, 2004, pp. 19-21. (In Russian).

[2] Zhevora S.V., Anisimov B.V., Simakov E.A., Oves E.V., Zebrin S.N. Potato: problems and prospects. Potato and Vegetables. 2019. No7. pp. 2-7.

[3] Semenov A V and Gavrilov V N 2017 A new method of germination of tubers of early potatoes Potat. Veget. 6 35-6.

[4] Byshov N V, Borychev S N, Simdyankin A A, Kolotov A S, Kolupaev S V, Kiryushin I N, Uspenskii I A, Shemyakin A V and Yukhin I A 2017 Modern view on potato production Polythematic network electronic scientific journal of the Kuban State Agrarian University 128 146-53

[5] Kolchin N.N., Ponomarev A.G., Zernov V.N. New machinery for potato growing. Potato and Vegetables. 2019. No6. pp. 26-29. 
[6] Kalimullin M., Abdrakhmanov R., Andreev R., Semenov A., Vasilyev O., Zaitsev P., Arkhipov S. (2017). Improvement of potato cultivation technology. IOP Conference Series: Earth and Environmental Science, p. 012017.

[7] Karpov M V, Shardina G E and Zhizdyuk A A 2018 Study of the effectiveness and economic evaluation of the application of the developed potato planting machine Agricul. Sci. J. 4. (LLC Amirit, Saratov) pp. 41-47.

[8] Simakov E A et al. 2009 Improving the efficiency of potato growing - an integrated approach Potat. Veget. (Institute of potato farming) 1 pp. 2-4.

[9] Rembalovich G K, Byshov N V, Borychev S N, Uspenskii I A, Ryazanov N A, Beznosyuk R V and Bulatov E P 2013 Innovative solutions harvesting and transport technological processes and technical means in potato Agricul. Machin. Tech. 1, pp. 23-25.

[10] Shardina G E and Karpov M V 2011 Justification kinematical parameters spoon-belt apparatus are planted Scientific Rev. (Saratov, LLC “APEX-94”) 4117. 